\title{
Estimation of the current stress field and fault reactivation analysis in the Asmari reservoir, SW Iran
}

\author{
Majid Taghipour $^{1} \cdot$ Mohammad Ghafoori $^{1}$. Gholam Reza Lashkaripour ${ }^{1} \cdot$ Nasser Hafezi Moghaddas ${ }^{1}$. \\ Abdullah Molaghab ${ }^{2}$
}

Received: 6 February 2018 / Published online: 10 June 2019

(c) The Author(s) 2019

\begin{abstract}
Knowing the current condition of the faults and fractures in a reservoir is crucial for production and injection activities. A good estimation of the fault reactivation potential in the current stress field is a useful tool for locating the appropriate spot to drill injection wells and to calculate the maximum sustainable pore pressure in enhanced oil recovery and geosequestration projects. In this study, after specifying the current stress state in the Gachsaran oilfield based on Anderson's faulting theory, the reactivation tendency of four faults (F1, F2, F3, and F4) in the Asmari reservoir is analyzed using 3D Mohr diagrams and slip tendency factors. Results showed that all the faults are stable in the current stress state, and F2 has the potential to undergo the highest pore pressure build-up in the field. On the other hand, F3 has the proper conditions (i.e., strike and dip referring to $\sigma_{\mathrm{Hmax}}$ orientation) for reactivation. Stress polygons were also applied to show the effect of the pore pressure increase on fault stability, in a graphical manner. According to the results, the best location for drilling a new injection well in this part of the field is the NW side of F2, due to the lower risk of reactivation. It was found that both methods of 3D Mohr diagrams and slip tendency factors predict similar results, and with the lack of image logs for stress orientation determination, the slip tendency method can be applied. The results of such studies can also be used for locating safe injection points and determining the injection pressure prior to numerical modeling in further geomechanical studies.
\end{abstract}

Keywords Asmari reservoir · Fault reactivation · 3D Mohr diagram · Slip tendency · Normal faulting regime

\section{Introduction}

The risk of pre-existing faults and fractures reactivating in current stress fields is of great importance in gas production/injection activities. The possible consequences of such reactivation have been investigated by many researchers in the past decade (e.g., Rutqvist et al. 2007; Kulikowski et al. 2016; Vilarrasa et al. 2016; Rutqvist et al. 2017). Breaching the hydraulic integrity of the caprock by creating or enhancing leakage conduits (Wiprut and Zoback 2002; Hawkes et al. 2005; Langhi et al. 2010) and induced seismicity in the area (Hsieh and Bredehoft 1981; Zoback and Gorelick

Edited by Jie Hao

Mohammad Ghafoori

ghafoori@um.ac.ir

1 Department of Geology, Faculty of Science, Ferdowsi University of Mashhad, Mashhad, Iran

2 National Iranian South Oil Company (NISOC), Ahwaz, Iran
2012; Rutqvist et al. 2013, 2017) are two examples of such consequences. On the other hand, the economic benefits of gas injection for enhanced oil recovery (EOR) and profitable results derived from greenhouse gases mitigation through $\mathrm{CO}_{2}$ sequestration cannot be neglected (Shukla et al. 2010). The evaluation of the stability of pre-existing faults and estimating the maximum safe pore pressure are conducted through geomechanical studies of reservoir and caprock in sedimentary basins. These data are crucial for reservoir stimulation procedures in EOR activities (Konstantinovskaya et al. 2012). Therefore, in order to carry out safe gas injection and storage, critically stressed fractures in the current stress field should be identified, and the maximum sustainable pore pressure created by this injection should be calculated using analytical or numerical methods (Morris et al. 1996; Reynolds et al. 2003; Streit and Hillis 2004; Hawkes et al. 2005; Mildren et al. 2005; Rutqvist et al. 2007; Teatini et al. 2014). Slip tendency analysis introduced by Morris et al. (1996) considers that the propensity of a fault surface to slip in a given stress field depends on the surface 


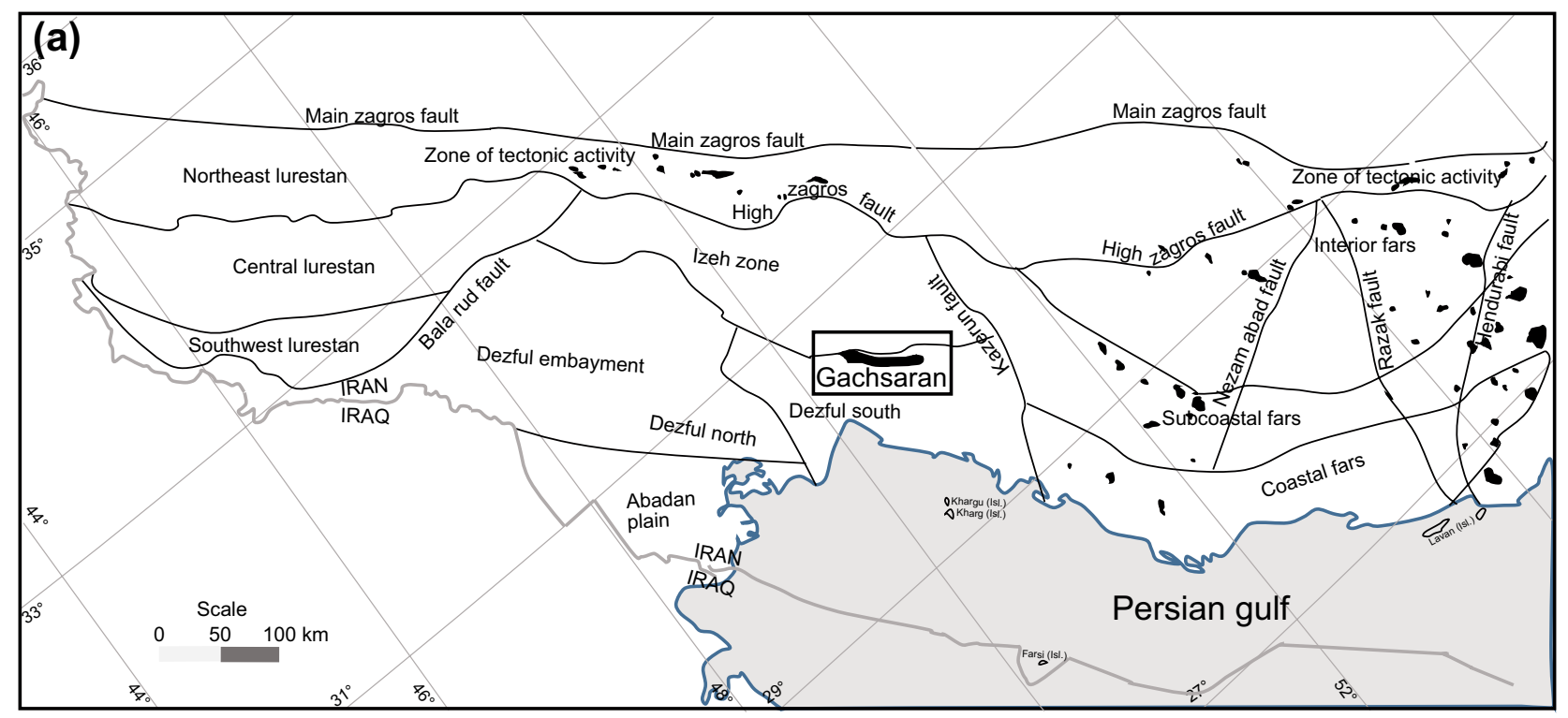

(b)

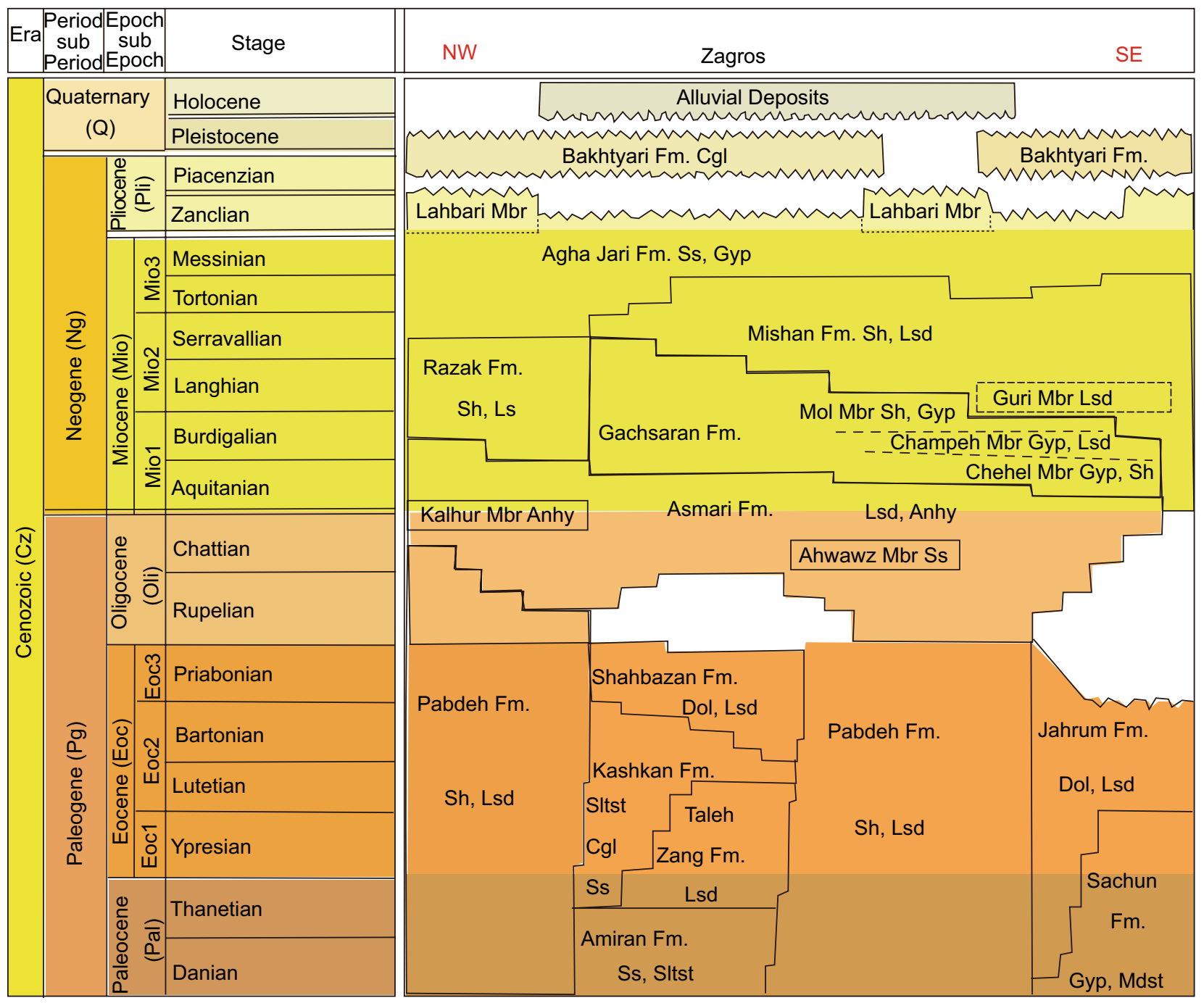


4Fig. 1 a The location of the Gachsaran oilfield in the Zagros foldthrust belt (Shaban et al. 2011), b the stratigraphic column of the field (Geological Society of Iran, GSI)

frictional characteristics, and was defined as the ratio of shear to normal stress acting on the surface. Rutqvist et al. (2007) showed that the maximum sustainable injection pressure or critical pore pressure $\left(P_{\mathrm{C}}\right)$ required to induce slip, can be estimated from slip tendency parameters. The intent of this study is to estimate the present-day stress magnitudes and orientations in Gachsaran oilfield and investigating the fault stability in both current and after-injection stress fields needed for oil recovery in the Asmari reservoir. These goals were achieved by plotting 3D Mohr diagrams and calculating the slip tendency factors introduced by Morris et al. (1996) and Hawkes et al. (2005). The maximum sustainable pore pressure was also estimated by these methods. Finally, the effect of pore pressure increase on stress magnitude is shown by stress polygons.

\section{Geological setting}

Gachsaran oilfield is situated in the Iranian section of the Zagros fold-thrust belt, a belt which stretches from the Anatolian fault in eastern Turkey to the Minab fault near the Makran region in the southeast of Iran. This foldthrust belt is a part of an active foreland basin complex, which was initiated in the late Tertiary time by the collision between the Iranian and Arabian Plates (Stocklin 1974; Berberian and King 1981). This field is an elongated doubly plunging anticlinal structure with dimensions of $65 \mathrm{~km}$ in length and 4-8 km in width and is considered one of the most important productive oilfields in the Oligocene-Lower Miocene carbonate horizons (Asmari formation) and the Middle Cretaceous carbonate horizons (Sarvak formation) (Shaban et al. 2011). The Asmari reservoir, which is characterized by its $30^{\circ}$ API and low sulfur content oil, produces almost 85 percent of total Iranian crude oil and is one of the most known reservoirs in the world (Rezaie and Nogole-Sadat 2004). This reservoir first was discovered by Anglo-Persian Oil Company in 1931 and had a peak production of 180 thousand barrels per day in 1976. The Asmari formation consists of cream to gray limestone, dolomitic limestone, and dolomite and its thickness in the type section is $314 \mathrm{~m}$ (Darvishzadeh 2009). The caprock of this oilfield is a Miocene aged formation called the Gachsaran formation, which consists of seven members. This formation is composed of anhydrite, limestone, and bituminous shale, and its oldest and the lowermost member, which is the caprock of the Asmari reservoir, is called member 1 (James and Wynd 1965). The average thickness of member 1 in this field is about $40 \mathrm{~m}$
(Darvishzadeh 2009). The lower contact of the Asmari formation is the Pabdeh formation, which is the source rock with the age of Paleocene to Eocene. The location of Gachsaran oilfield and the Cenozoic era of stratigraphic column in Zagros fold-thrust belt are shown in Fig. 1.

The four faults F1, F2, F3, and F4 have been analyzed in this study (Fig. 2). All of them are normal faults, and there is no information about their cohesion strength $(C)$ and the coefficient of static friction $(\mu)$. Since the cohesion of the weakness (pre-existing fault) can be neglected, they were considered cohesionless (i.e., $C=0$ ). Byerlee (1978) demonstrated that the coefficient of static friction is between 0.85 when confining pressure is less than $200 \mathrm{MPa}$ and 0.6 for more than $200 \mathrm{MPa}$. It is recommended that in the absence of such data, the coefficient of static friction can be set to 0.6 (Rutqvist et al. 2007; Zoback 2007). The structural and mechanical characteristics of the faults are summarized in Table 1.

\section{Methodology}

In order to investigate the reactivation tendency of these faults, some of the geomechanical parameters and the current stress field were calculated using well logs. For this goal, $\mathrm{P}$ - and $\mathrm{S}$-wave velocities were used to estimate the dynamic elastic properties of rocks such as Young's modulus and Poisson's ratio. Then the static elastic properties were calculated using relationships derived in the National Iranian South Oil Company (NISOC) laboratory. Since these relationships were not published before, their accuracy was tested by an equation derived in another oilfield from the same reservoir in the area. In the next step, the vertical stress magnitude was calculated by using the density log (RHOB) at the desired depth. The orientations of the minimum and the maximum horizontal stresses were identified by interpreting image logs, and their magnitudes were estimated using poroelastic equations. Pore pressure estimations were made based on Eaton's (1975) empirical relationship modified for an Iranian field, and its accuracy was controlled by in situ pore pressure measurements carried out in a well. In order to investigate the possibility of fault slippage, 3D Mohr diagrams were applied to determine the present state of each fault in the stress field. Using Morris et al. (1996) and Hawkes et al. (2005) equations, the slip tendency and modified slip tendency for the current stress state and pore pressure, for each of the faults, were calculated, and the maximum sustainable pore pressure increase caused by injection was also computed. Finally, by plotting stress polygons, the effect of pore pressure increase on the stress field is shown in an illustrative manner. 
Fig. 2 UGC map of the Asmari reservoir showing the location of the faults. (C.R. is Caprock and As. is Asmari Formation)

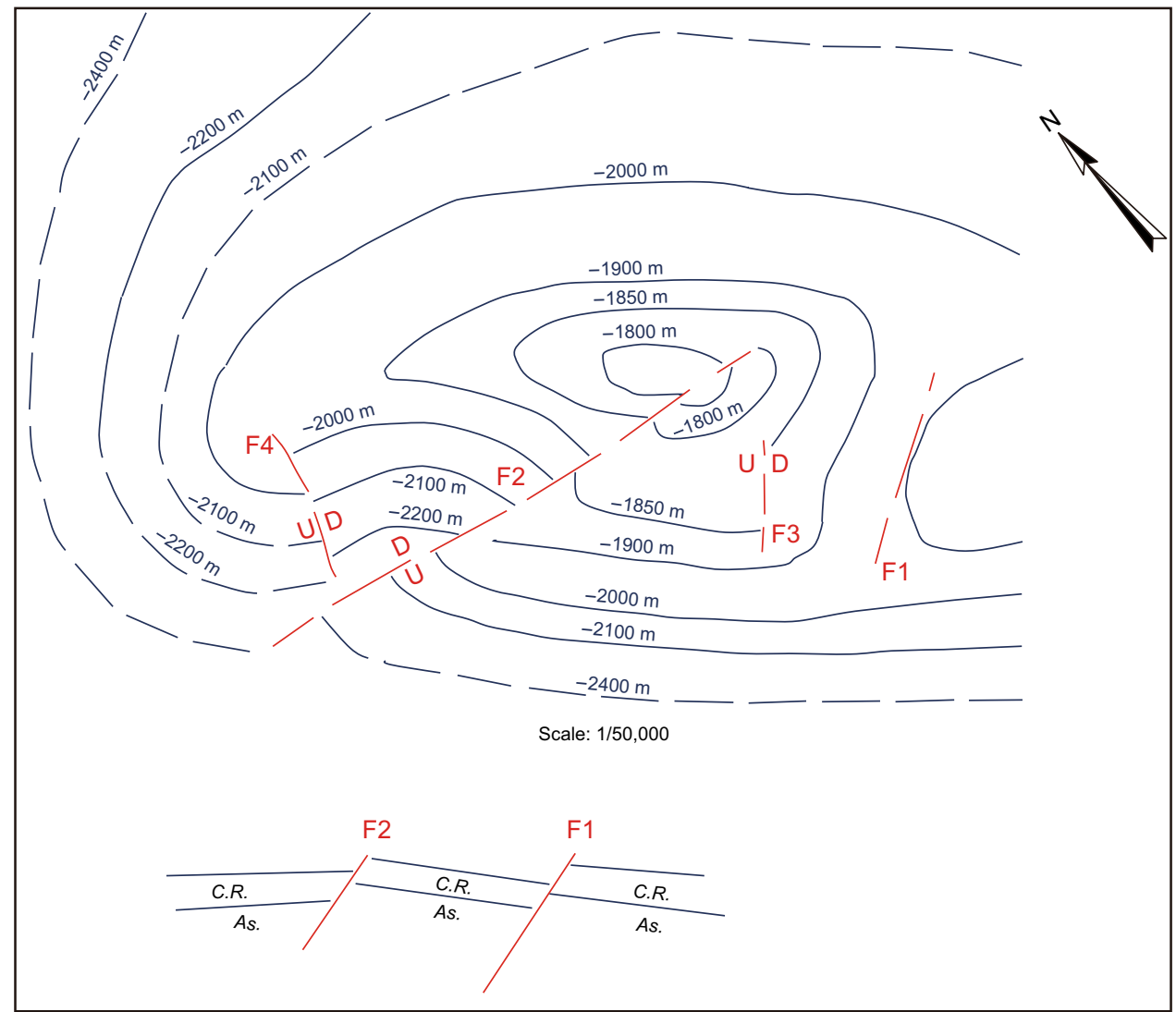

Table 1 Structural and mechanical properties of faults

\begin{tabular}{|c|c|c|c|c|c|c|}
\hline Fault & Dip, ${ }^{\circ}$ & Dip direction, ${ }^{\circ}$ & Strike, ${ }^{\circ}$ & $C, \mathrm{MPa}$ & $\mu$ & Description \\
\hline F1 & 52 & 319 & 229 & 0 & 0.6 & $\begin{array}{l}\text { A normal fault that cuts out about } 50 \mathrm{~m} \text { of the lower part of caprock } \\
\text { and the upper part of Asmari formation }\end{array}$ \\
\hline $\mathrm{F} 2$ & 80 & 8 & 278 & 0 & 0.6 & A normal fault that cuts out about $20 \mathrm{~m}$ of the upper part of the caprock \\
\hline F3 & 59 & 130 & 40 & 0 & 0.6 & A normal fault breached a small part of caprock \\
\hline F4 & 44 & 141 & 51 & 0 & 0.6 & $\begin{array}{l}\text { A normal fault that cuts out the caprock completely, and } 78 \mathrm{~m} \text { of the } \\
\text { top of the Asmari formation }\end{array}$ \\
\hline
\end{tabular}

\section{Theory and background}

\subsection{Elastic properties}

The speed of elastic waves in solids is linked to the elastic moduli and bulk density $\rho$ by the wave equation (Mavko et al. 2009). In order to estimate the magnitude of elastic moduli in rocks, knowing the magnitude of seismic velocities $\left(V_{\mathrm{P}}\right.$ and $\left.V_{\mathrm{S}}\right)$ is essential. Since the dipole shear sonic imager (DSI) was not available in the field, $V_{\mathrm{S}}$ magnitude was estimated using the rock physical model introduced by Xu and Payne (2009). In this method, for predicting the S-wave log, both matrix and porosity of rock will be modeled. At the beginning, the $V_{\mathrm{P}} \log$ was modeled, and then the best match between the modeled $V_{\mathrm{P}}$ and the directly measured $V_{\mathrm{P}}$ from the $\mathrm{d} t \log$ was used to estimate $V_{\mathrm{S}}$. After that, the dynamic Poisson's ratio and Young's modulus were calculated as follows:

$v_{\mathrm{d}}=\frac{1}{2} \frac{\left(V_{\mathrm{P}} / V_{\mathrm{S}}\right)^{2}-2}{\left(V_{\mathrm{P}} / V_{\mathrm{S}}\right)^{2}-1}$

$E_{\mathrm{d}}=2 \rho V_{\mathrm{S}}^{2}(1+v)$

where $V_{\mathrm{P}}$ and $V_{\mathrm{S}}$ are the P-wave and $\mathrm{S}$-wave velocities, $\nu_{\mathrm{d}}$ is the dynamic Poisson's ratio, and $E_{\mathrm{d}}$ is the dynamic Young's modulus.

In most cases, the static moduli are different from the dynamic ones. One reason is that stress-strain relations for 


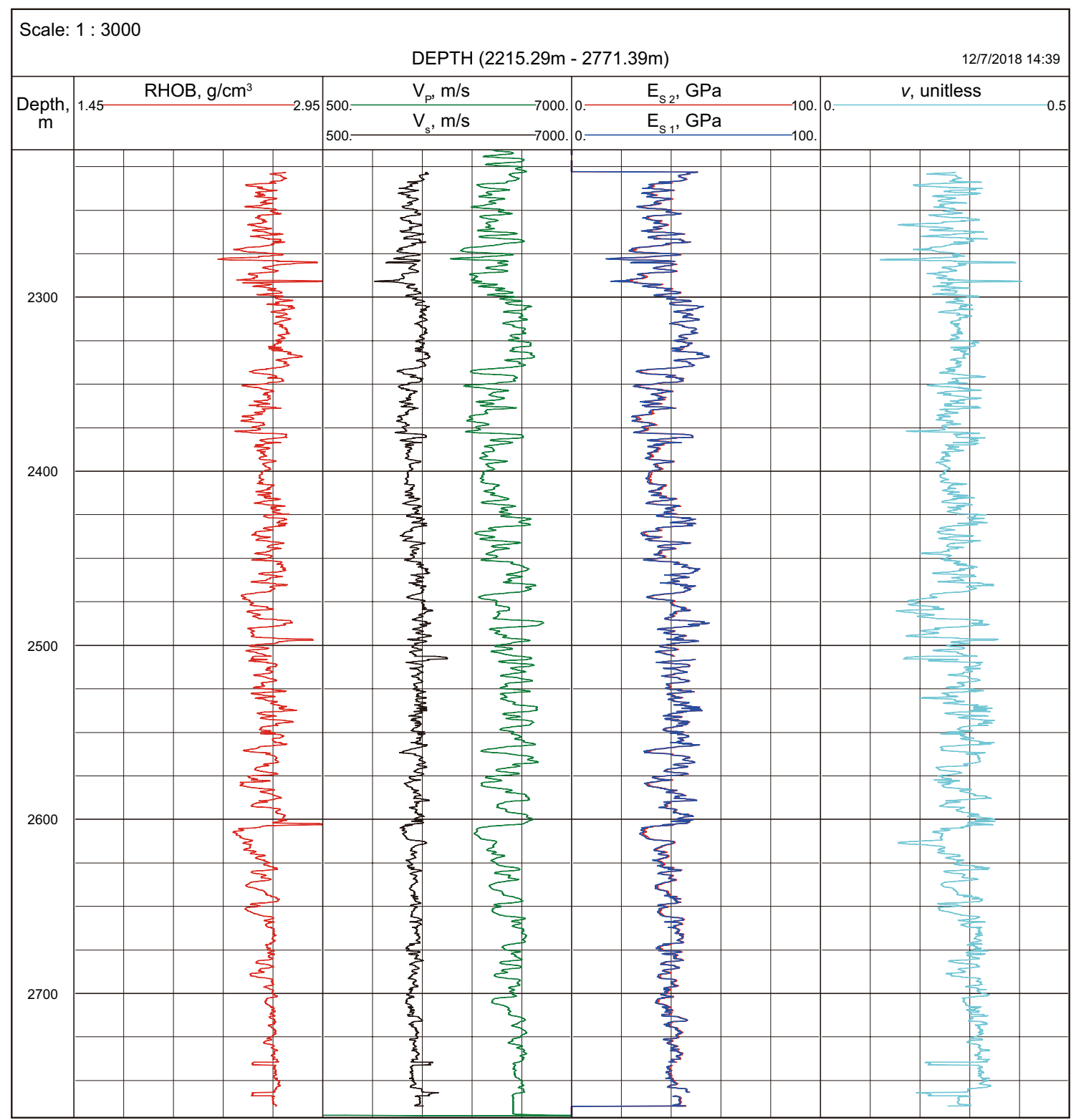

Fig. 3 Logs of density (RHOB), velocity (real $V_{\mathrm{P}}$ and modeled $V_{\mathrm{S}}$ ), static Young's modulus $\left(E_{\mathrm{S}}\right)$, and Poisson's ratio $(\nu)$ for the Asmari reservoir in a well. $E_{\mathrm{S} 1}$ and $E_{\mathrm{S} 2}$ are calculated by the NISOC and Seyed Sajadi and Aghighi equations, respectively

rocks are often nonlinear. Another reason is that rocks are often inelastic. Also, there are no universal relationships between static and dynamic moduli, since the conditions of measurements (e.g., effective pressure and pore fluid) affect the elastic wave velocity and the derived elastic moduli in a sample (Mavko et al. 2009). In this article, an equation derived by NISOC laboratory (Eq. 3) was used to convert a dynamic Young's modulus to a static one. In order to evaluate the validity of this relationship, the Seyed Sajadi and Aghighi (2015) equation (Eq. 5) was used to calculate the static Young's modulus.

$E_{\mathrm{s}}=0.7 \times E_{\mathrm{d}} \quad$ NISOC laboratory (unpublished) $v_{\mathrm{s}}=v_{\mathrm{d}}$

$E_{\mathrm{s}}=\left(0.731 \times E_{\mathrm{d}}\right)-2.337 \quad$ Seyed Sajadi and Aghighi (2015)

In these equations, $E_{\mathrm{S}}$ is the static Young's modulus, and $\nu_{\mathrm{S}}$ is the static Poisson's ratio. Figure 3 shows the elastic moduli calculated by Eqs. 3-5. As it can be seen, the static Young's moduli estimated by Eqs. 3 and $5\left(E_{\mathrm{S} 1}\right.$ and $\left.E_{\mathrm{S} 2}\right)$ show a good overlap. 


\subsection{In situ stresses magnitudes and orientations}

Determining the magnitudes and orientations of the principal stresses is imperative in any fault reactivation analysis. The regional stress field at any given depth consists of three principal stress magnitudes: the vertical stress $\left(\sigma_{\mathrm{V}}\right)$ usually considered to be solely due to the weight of the overburden, the minimum horizontal stress $\left(\sigma_{\mathrm{hmin}}\right)$, and the maximum horizontal stress $\left(\sigma_{\mathrm{H} \max }\right)$ (Kidambi and Kumar 2016). Mathematically, the magnitude of vertical stress $\sigma_{\mathrm{V}}$ can be calculated by integration of rock densities from the surface to the depth of interest, $z$ (Zoback et al. 2003):

$\sigma_{\mathrm{V}}=\int_{0}^{z} \rho(z) g \mathrm{~d} z \approx \bar{\rho} g z$

where $\rho(z)$ is the density as a function of depth, $g$ is the gravitational acceleration constant, and $\bar{\rho}$ is the mean overburden density. As the available density logs were collected from a certain depth in the reservoir, an average density of about $2.3 \mathrm{~g} / \mathrm{cm}^{3}$ was considered for calculating $\sigma_{\mathrm{V}}$ to the ground surface.

A typical approach to estimate the least principal stress is called the leak-off test (LOT). LOTs are conducted after the casing has been cemented in place and the casing shoe is drilled out a short distance ( $\sim \mathrm{m}$ ) (Zoback et al. 2003). By pumping at a constant rate into a well, the pressure will increase linearly with time, as the volume of the system is fixed. The point at which a distinct deviation occurs from the linear increase of wellbore pressure with time is called the leak-off point (LOP). At LOP, a hydraulic fracture must exist. If the LOP is not reached, a limited test, which is called formation integrity test (LT or FIT) is conducted. Such tests simply indicate that at the maximum pressure achieved, the fluid did not propagate away from the wellbore wall, and this pressure was not enough to create a fracture or did not exceed the least principal stress if a fracture was initiated (Zoback et al. 2003). The FIT does not provide any information about the magnitude of the least principal stress (Konstantinovskaya et al. 2012); however, it can be used as an indicator of the lower bound of $\sigma_{\text {hmin }}$, because the pressure at FIT will always be less than the least principal stress (Fig. 4). Since the FIT was carried out in the field, the magnitudes of the minimum and maximum horizontal stresses were also calculated by the poroelastic horizontal strain model Fjaer et al. (2008), as follows:

$$
\begin{gathered}
\sigma_{\mathrm{hmin}}=\frac{v}{1-v} \sigma_{\mathrm{V}}+\frac{1-2 v}{1-v} P_{\mathrm{P}}(\alpha)+\frac{E}{1-v^{2}} \varepsilon_{x}+\frac{v E}{1-v^{2}} \varepsilon_{y} \\
\sigma_{\mathrm{H} \max }=\frac{v}{1-v} \sigma_{\mathrm{V}}+\frac{1-2 v}{1-v} P_{\mathrm{P}}(\alpha)+\frac{E}{1-v^{2}} \varepsilon_{y}+\frac{v E}{1-v^{2}} \varepsilon_{x}
\end{gathered}
$$

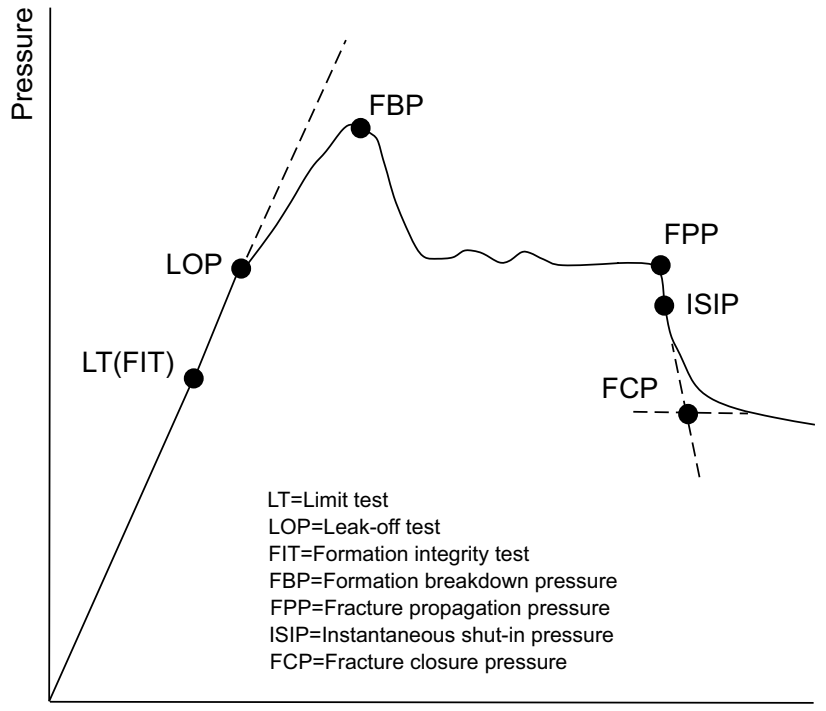

Volume

Fig. 4 An extended LOT schematic illustration (adapted from Konstantinovskaya et al. 2012). The magnitude of the least principal stress is nearly equal to leak-off test (LOP) or instantaneous shut-in pressure (ISIP) $\left(\mathrm{LOP} \approx \mathrm{ISIP} \approx \sigma_{\mathrm{hmin}}\right)$. The formation integrity test (FIT) does not yield any specific information about the $\sigma_{\mathrm{hmin}}$, but it is always lower than $\sigma_{\mathrm{hmin}}$

In these equations, $\sigma_{\mathrm{V}}$ is the vertical stress, $P_{\mathrm{P}}$ is pore pressure (in MPa), $\alpha$ is the Biot's coefficient (which was considered 1 to account for the brittle failure of rocks), $E$ is the static Young's modulus (in GPa), and $\nu$ is Poisson's ratio. $\varepsilon_{x}$ and $\varepsilon_{y}$ are the magnitudes of the rock deformation in the $x$ and $y$ planes, which can be calculated as a function of the overburden stress as Eqs. 9 and 10:

$\varepsilon_{x}=\frac{\sigma_{\mathrm{V}} \times v}{E} \times\left(\frac{1}{1-v}-1\right)$

$\varepsilon_{y}=\frac{\sigma_{\mathrm{V}} \times v}{E} \times\left(1-\frac{v^{2}}{1-v}\right)$

Observations of stress-induced breakouts are a very effective technique for determining stress orientation in wells and boreholes. The most reliable way to observe these features in a well is through the use of ultrasonic image logs. The borehole breakouts and the drilling-induced tensile fractures are caused by hoop stress and radial stress, respectively (Zoback 2007). In vertical wells, the breakouts form at the azimuth of the minimum horizontal compressive stress, and drillinginduced tensile fractures form in the wall of the borehole at the azimuth of the maximum horizontal compressive stress when the circumferential stress acting around the well locally goes into tension. According to Wiprut et al. (2000), drilling-induced tensile fractures can define stress orientations with great detail and precision. In this research, an 
Fig. 5 Image log of a well with drilling-induced tensile fractures (pink lines), the prevailed azimuth of $\sigma_{\mathrm{Hmax}}$ is nearly $52^{\circ}$
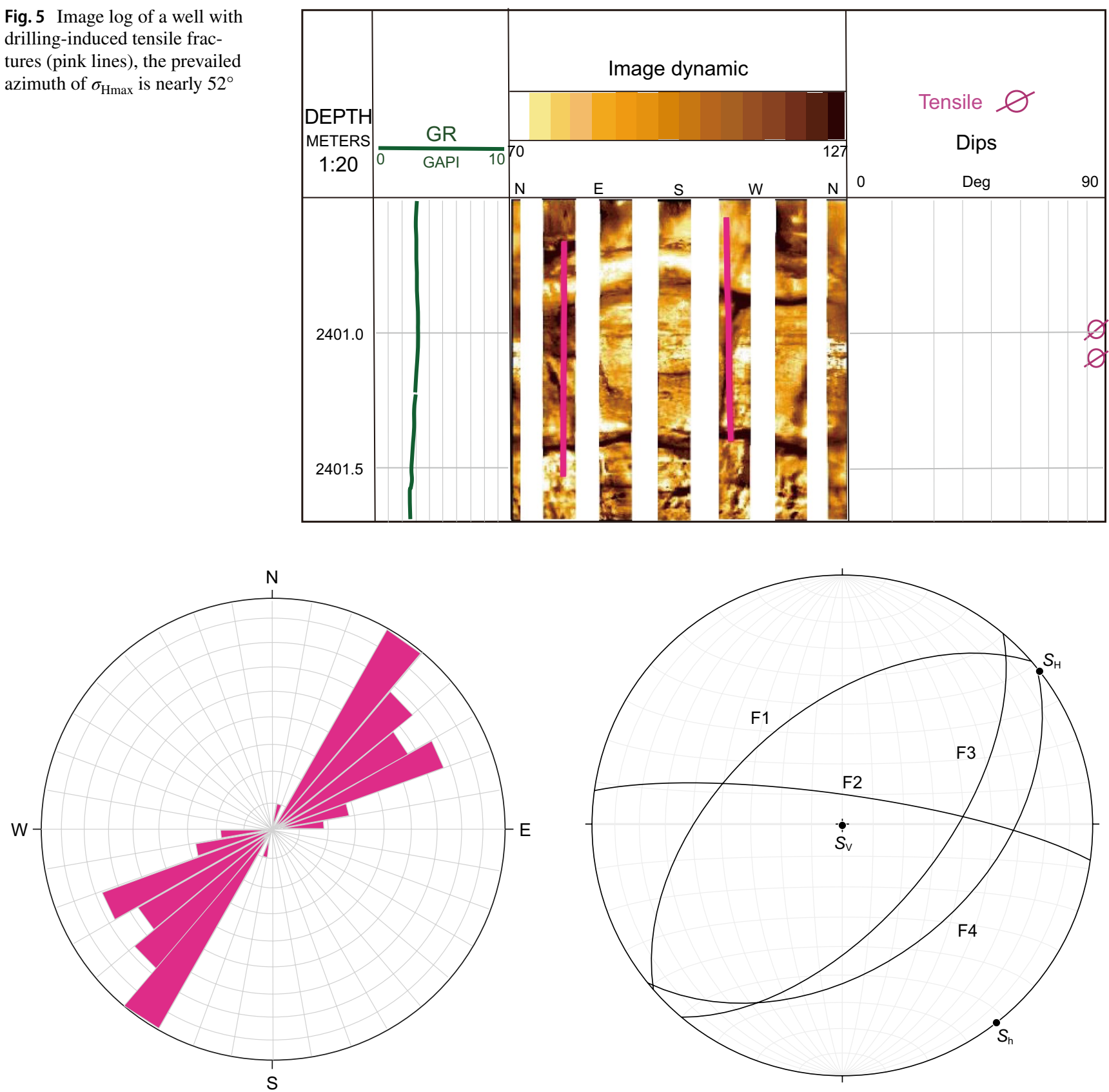

Fig. 6 Rose diagram showing the orientation of drilling-induced tensile fractures observed in the studied well

image $\log$ was interpreted to find the stress orientations in the field. Based on the drilling-induced fractures observed in the image $\log$, the azimuth of $\sigma_{\mathrm{H} \max }$ was determined. A total number of 32 fractures were observed in the studied well, with a prevailing azimuth of $52^{\circ}$ (the existence of drillinginduced tensile fractures is $90^{\circ}$ from the breakouts). The interpreted image log showing the drilling-induced tensile fractures and the rose diagram of identified fractures in the studied well are illustrated in Figs. 5 and 6, respectively.

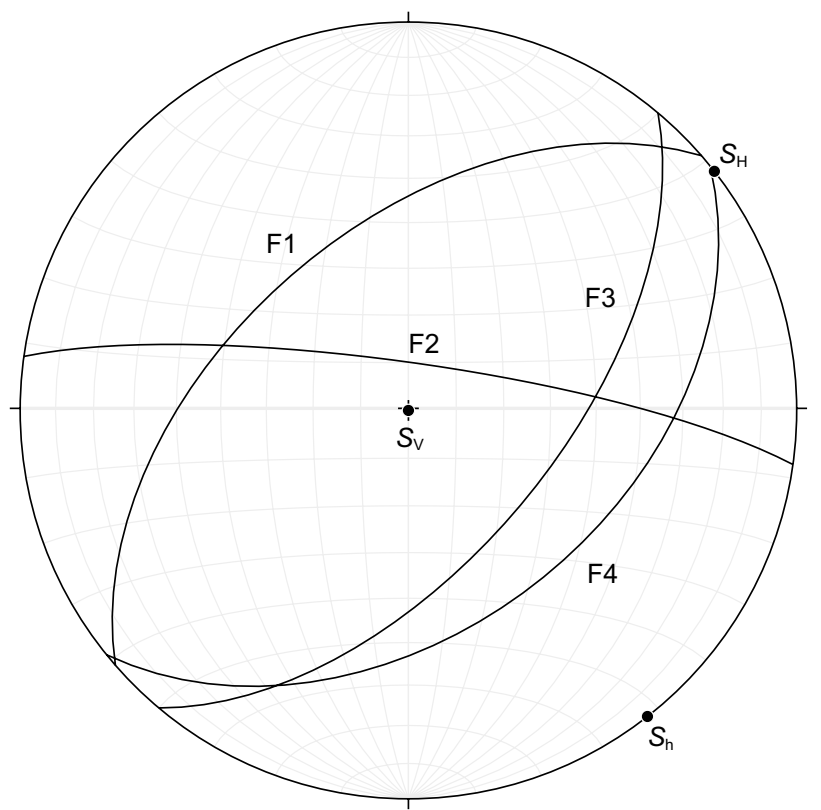

Fig. 7 Stereographic projection of fault planes and in situ stresses orientations

Figure 7 shows the fault planes and in situ stresses orientations in the lower hemisphere stereographic projection.

\subsection{Pore pressure}

A good estimation of pore pressure by using cost-effective predicting methods is essential for reservoir simulation studies. The Terzaghi hypothesis, which describes the compaction of soil due to overburden stress, is the basis of formation pore pressure prediction (Azadpour et al. 2015). In this 
(a) Stress, MPa

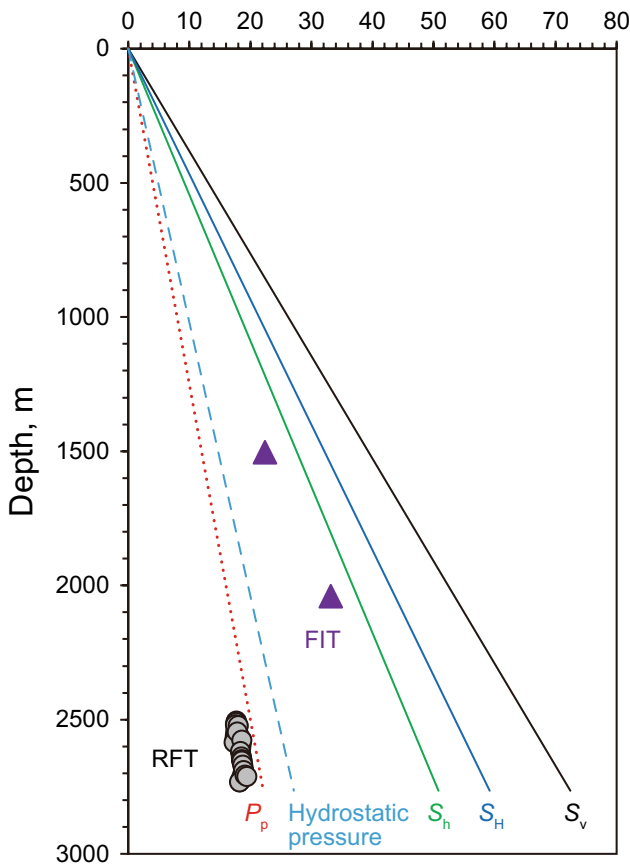

(b)

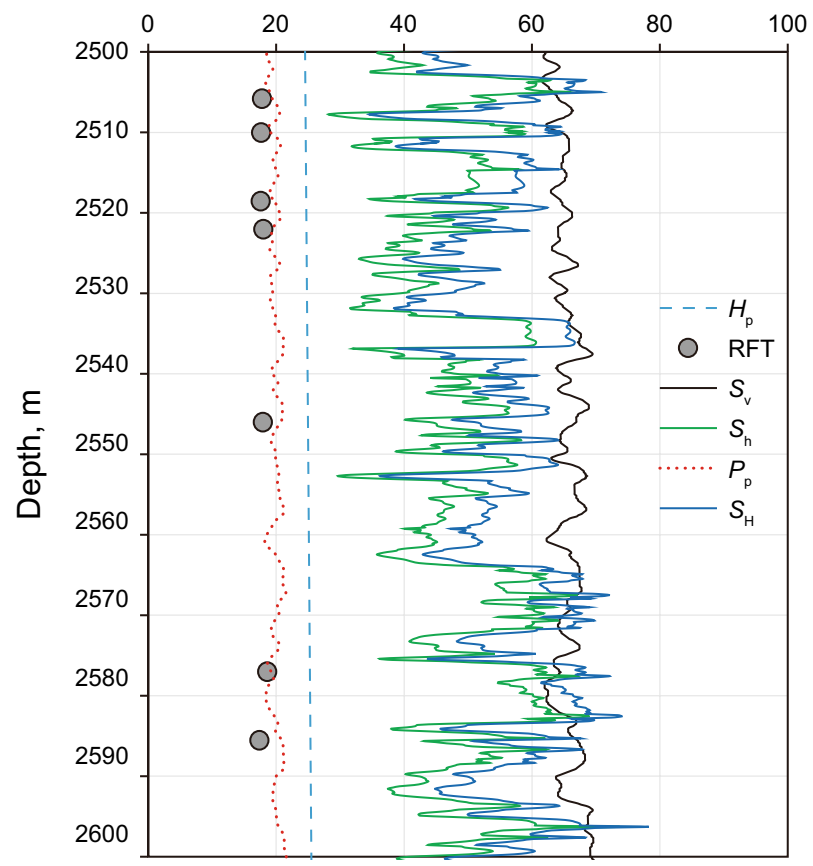

Fig. 8 Stress-depth plots showing the stress state in the Gachsaran oilfield (with the line of best fit) (left), and a well faulted by F2 (right). The gray points represent the formation fluid pressures (RFT), and triangles indicate FIT pressure (the stresses are calculated using the elastic moduli estimated by the NISOC equation)

study, the pore pressure was estimated by the modified Eaton (1975) method, delivered by Azadpour et al. (2015). The modified Eaton's equation is as follows:

$P_{\mathrm{pg}}=S_{\mathrm{g}}-\left(S_{\mathrm{g}}-P_{\mathrm{ng}}\right)\left(\frac{50+(185-50) e^{-0.00137 z}}{\Delta t}\right)^{x}$

where $P_{\mathrm{pg}}$ is the formation pressure gradient, $P_{\mathrm{ng}}$ is the hydrostatic pore pressure gradient which is suggested $1.049 \times 10^{-2} \mathrm{MPa} / \mathrm{m}(0.464 \mathrm{psi} / \mathrm{ft})$ for Iran, $\Delta_{t}$ is the measured sonic transit time by well logging, $z$ is depth, and $x$ is the exponent constant, which was determined as 0.5 by Azadpour et al. (2015) for a field in Iran. The overburden pressure gradient $S_{\mathrm{g}}$ can be calculated by the following equation:

$S_{\mathrm{g}}=0.433 \times \rho_{\mathrm{b}}$

where the $\rho_{\mathrm{b}}$ is the bulk density.

After calculating the pore pressure using Eqs. 11 and 12, the accuracy of this method was investigated by the direct measurements of formation fluid pressure obtained by a Repeat Formation Tester (RFT) in a limited number of wells in the field. Figure 8 is the stress-depth plot showing the general stress state of the field (left) and a well faulted by F2.

As it can be seen in Fig. 8, in this field the maximum principal stress $\left(\sigma_{1}\right)$ is $\sigma_{\mathrm{V}}$, and the intermediate and minimum
Table 2 Minimum, maximum, and average magnitudes of the geomechanical parameters for a well

\begin{tabular}{lcrrr}
\hline Parameter & \multicolumn{2}{l}{ Magnitude } & Interval, $\mathrm{m}$ \\
\cline { 2 - 4 } & \multicolumn{1}{c}{ Min } & \multicolumn{1}{c}{ Max } & \multicolumn{1}{c}{ Ave } & \\
\hline RHOB, g/cm & 2.1 & 2.9 & 2.6 & $2215-2771$ \\
$V_{\mathrm{P}}, \mathrm{m} / \mathrm{s}$ & 3834.4 & 6263.8 & 5273.3 & $2228-2764$ \\
$V_{\mathrm{S}}, \mathrm{m} / \mathrm{s}$ & 1855.0 & 3756.1 & 2907.1 & $2228-2764$ \\
$E_{\mathrm{d}}, \mathrm{GPa}$ & 22.1 & 88.8 & 56.5 & $2228-2764$ \\
$E_{\mathrm{s}}, \mathrm{GPa}$ & 15.5 & 62.2 & 39.5 & $2228-2764$ \\
$\nu_{\mathrm{s}}$ & 0.11 & 0.40 & 0.27 & $2228-2764$ \\
$\sigma_{\mathrm{V}}, \mathrm{MPa}$ & 36.2 & 72.6 & 63.7 & $2228-2764$ \\
$\sigma_{\mathrm{H}}, \mathrm{MPa}$ & 22.9 & 76.8 & 55.8 & $2228-2764$ \\
$\sigma_{\mathrm{h}}, \mathrm{MPa}$ & 19.2 & 72.7 & 49.1 & $2228-2764$ \\
$P_{\mathrm{P}}, \mathrm{MPa}$ & 13.7 & 22.7 & 18.9 & $2215-2771$ \\
\hline
\end{tabular}

principal stresses $\left(\sigma_{2}\right.$ and $\left.\sigma_{3}\right)$ are $\sigma_{\mathrm{Hmax}}$ and $\sigma_{\mathrm{hmin}}$, respectively. So, according to Anderson's faulting theory (Anderson 1951), this field is in a normal faulting regime (i.e., $\sigma_{1}>\sigma_{2}>\sigma_{3}$ ). The estimated (red line) and directly measured $P_{\mathrm{p}}$ (gray points in Fig. 8) shows a maximum difference of $2 \mathrm{MPa}$, which confirms an acceptable range for the accuracy of the Azadpour et al. (2015) method. The results of the measured geomechanical parameters for this well are also summarized in Table 2. As it can be seen in both Fig. 8 and 


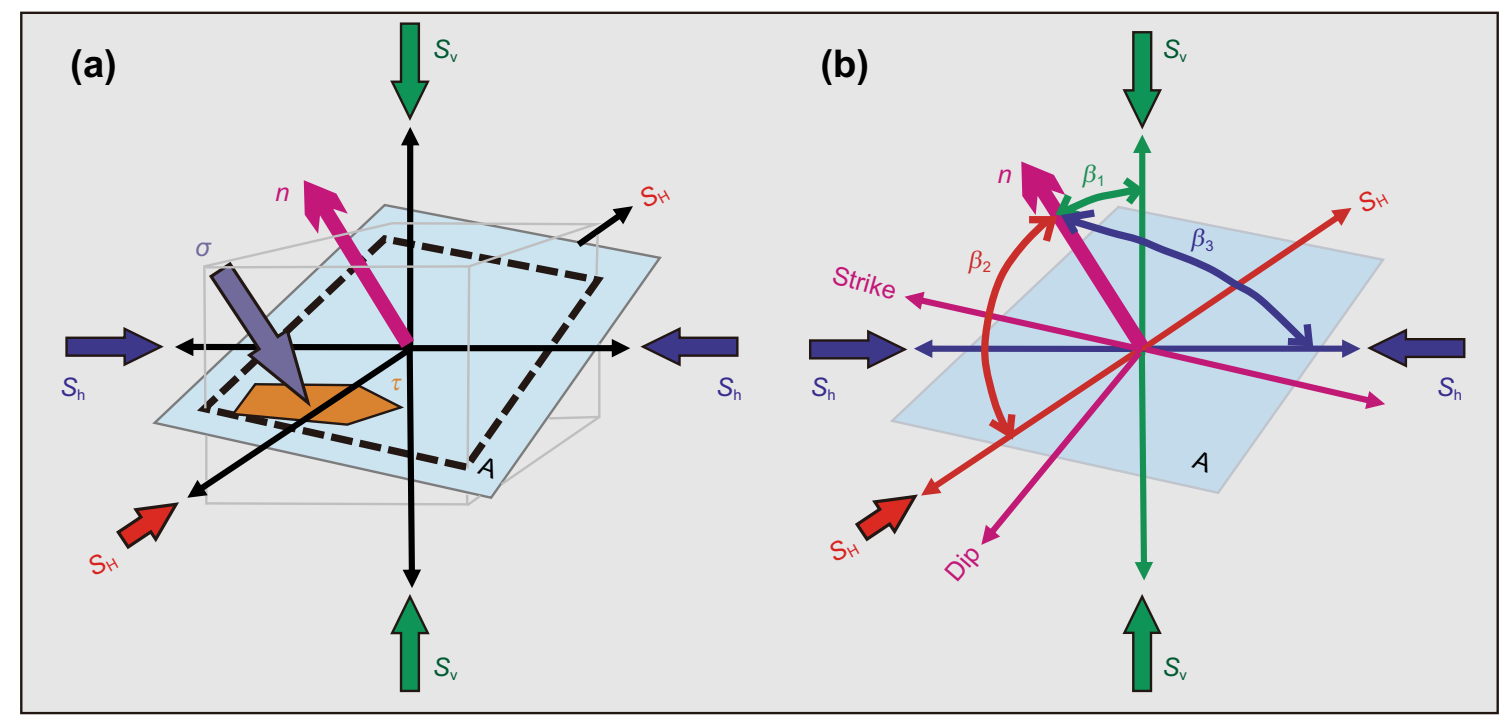

Fig. 9 a Resolved normal $(\sigma)$ and shear $(\tau)$ stress on plane A. b Orientation of the potential slip plane A in terms of three angles $\beta_{1}, \beta_{2}$, and $\beta_{3}$ from the coordinate axes of the principal stresses. Adopted from Schmitt (2014)

Table 2, the horizontal stresses in some depth are higher than the vertical stress, which is caused by stress perturbation resulted from faulting.

\section{Three-dimensional Mohr diagrams}

One of the best ways to show the shear and normal stresses acting on arbitrarily oriented faults in three dimensions is Mohr diagrams (Zoback 2007). These diagrams are also used to explain the mechanism of faulting and reactivation of pre-existing faults (Yin and Ranalli 1992; Jolly and Sanderson 1997; McKeagney et al. 2004; Streit and Hillis 2004; $\mathrm{Xu}$ et al. 2010). In 3D Mohr diagrams, the values of three principal stress $\sigma_{1}, \sigma_{2}$, and $\sigma_{3}$ are used to define three Mohr circles. Faults can be shown by a point, located in the space between the two small Mohr circles (defined by the differences between $\sigma_{1}$ and $\sigma_{2}$, and $\sigma_{2}$ and $\sigma_{3}$, respectively), and the big Mohr circle (defined by the difference between $\sigma_{1}$ and $\sigma_{3}$ ) (Zoback 2007). The position of this point defines the shear and normal stresses on the fault plane. These stresses can be readily calculated using the following equations:

$\sigma_{\mathrm{n}}=\sigma_{\mathrm{V}}\left(\cos \beta_{1}\right)^{2}+\sigma_{\mathrm{H}}\left(\cos \beta_{2}\right)^{2}+\sigma_{\mathrm{h}}\left(\cos \beta_{3}\right)^{2}$

$\tau=\sqrt{\sigma_{\mathrm{V}}^{2}\left(\cos \beta_{1}\right)^{2}+\sigma_{\mathrm{H}}^{2}\left(\cos \beta_{2}\right)^{2}+\sigma_{\mathrm{h}}^{2}\left(\cos \beta_{3}\right)^{2}-\sigma_{\mathrm{n}}^{2}}$

where $\sigma_{\mathrm{n}}$ is the normal stress and $\tau$ is the shear stress. $\beta_{1}, \beta_{2}$, and $\beta_{3}$ are the angles between the surface normal (n) and the axes of the greatest, the intermediate, and the least principal stresses, respectively. Figure 9 shows the normal and shear stresses acting on a plane, and the orientation of this plane in the stress field defined by three angles of $\beta_{1}, \beta_{2}$, and $\beta_{3}$. In this study, we used the open source MohrPlotter software to calculate these angles and the stresses on the fault planes.

Estimating the maximum sustainable pore pressure can be achieved by calculating the fluid pressure increase required to induce failure on faults. In a Mohr diagram, this pore pressure increase is the difference between the effective normal stress acting on a fault segment and the effective normal stress required to cause failure on this segment (Streit and Hillis 2004). In this research, the 3D Mohr diagrams were plotted for the faults (Fig. 10), and the effective normal and shear stresses on their planes were calculated $\left(\sigma_{\mathrm{ni}}^{\prime}, \tau\right)$. In the next step, the maximum sustainable pore pressure $\left(P_{\text {pmax }}\right)$ due to gas injection and the corresponding effective normal stress at the failure point $\left(\sigma_{\mathrm{nf}}^{\prime}\right)$ for each fault were obtained by moving the Mohr circle to the left as much as possible until it touched the failure envelope (Fig. 11). The results are summarized in Table 3.

As Fig. 10 shows, none of the faults is critically stressed in the current stress field. According to these diagrams, $\mathrm{F} 1, \mathrm{~F} 3$, and F4 are on the large Mohr circle $\left(\sigma_{1}-\sigma_{3}\right)$ and are parallel to $\sigma_{2}$, which in this case is $\sigma_{\mathrm{Hmax}} . \mathrm{F} 2$ is on the small circle $\left(\sigma_{2}-\sigma_{3}\right)$ and is nearly parallel to $\sigma_{1}$, which is $\sigma_{\mathrm{V}}$ in this field. According to the results presented in Table 3 , the highest pore pressure increase required for reactivation is for $\mathrm{F} 2\left(\Delta P_{\mathrm{p}}=35.4 \mathrm{MPa}\right)$. 

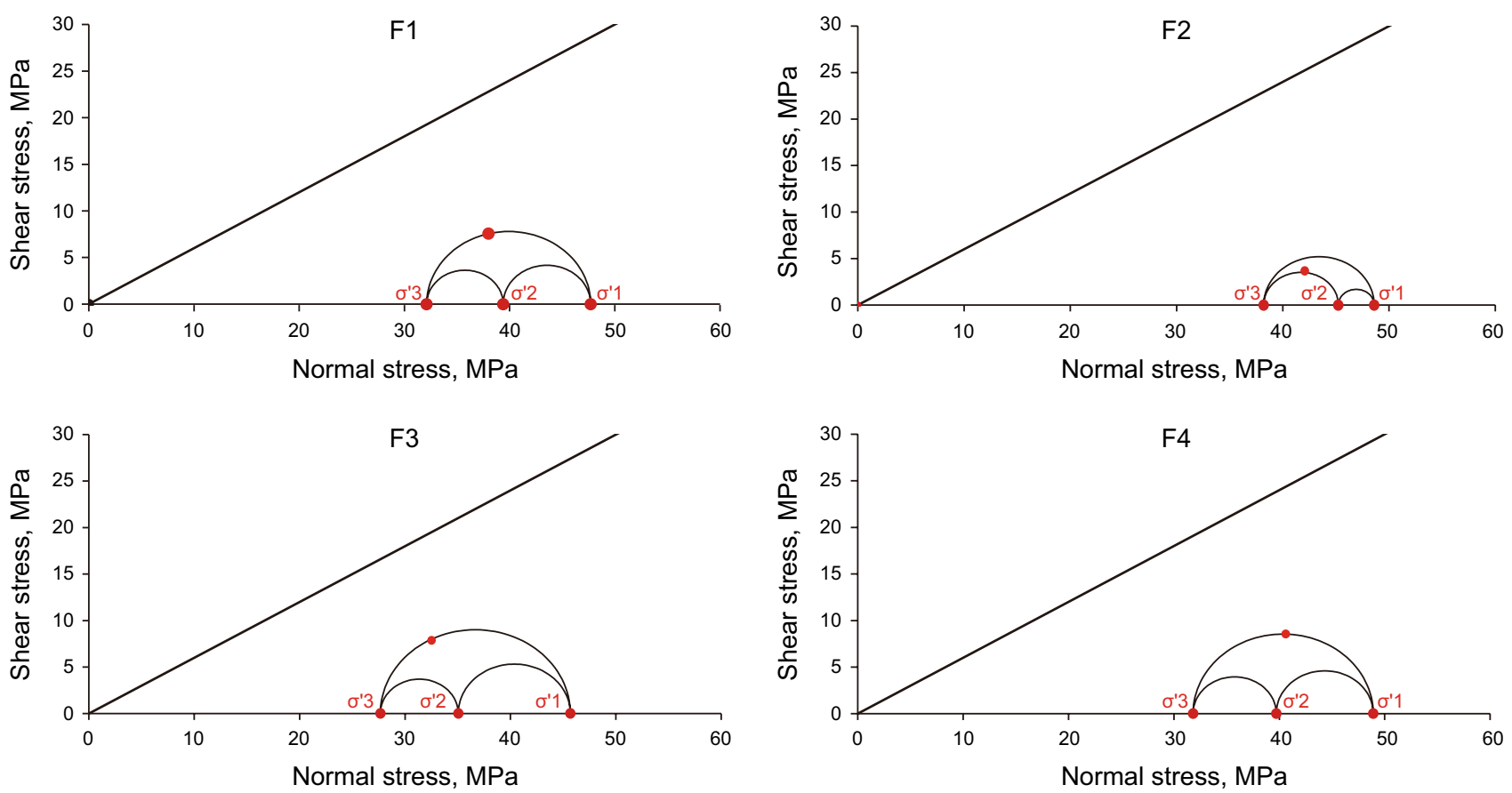

Fig. 10 3D Mohr diagrams of four faults F1, F2, F3, and F4 (using the NISOC equation). As can be seen, none of the faults is critically stressed, and all of them are stable in the current stress field and pore pressure

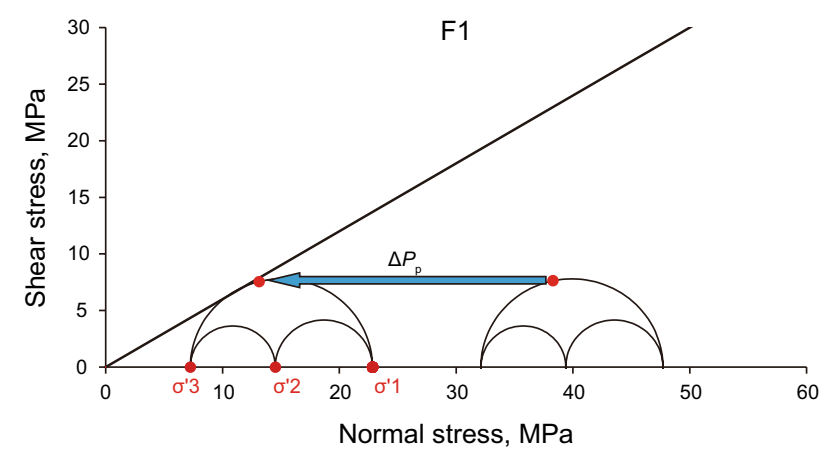

Fig. 11 Mohr diagram plotted for F1 for estimating critically stressed pore pressure. The pore pressure increase to cause failure $\left(\Delta P_{\mathrm{p}}\right)$ for this fault is about $24.9 \mathrm{MPa}$

\section{Slip tendency parameter}

Reactivation of pre-existing faults may create leakage conduits that will risk the seal capacity in an injection project. The slip will occur on a fault when the maximum shear stress acting on the fault plane exceeds the shear strength of the fault. Slip tendency is a method that allows quick assessment of stress states and related potential fault activity (Morris et al. 1996). Using two-dimensional stress equations given by Jaeger and Cook (1969), the values of shear and normal stresses on the fault plane can be calculated as follows:

$$
\begin{aligned}
& \sigma_{\mathrm{n}}=\frac{\left(\sigma_{1}+\sigma_{3}\right)}{2}-\frac{\left(\sigma_{1}-\sigma_{3}\right)}{2} \cos 2 \theta \\
& \tau=\frac{\left(\sigma_{1}-\sigma_{3}\right)}{2} \sin 2 \theta
\end{aligned}
$$

Table 3 Effective normal and shear stress, initial pore pressure $\left(P_{\mathrm{pi}}\right)$, the maximum sustainable pore pressure $\left(P_{\mathrm{pmax}}\right)$, pore pressure increase $\left(\Delta P_{\mathrm{p}}\right)$, and normal stress at failure point $\left(\sigma_{\mathrm{nf}}^{\prime}\right)$ for the faults

\begin{tabular}{lllllllr}
\hline Fault & Equation & $\sigma_{\mathrm{ni}}^{\prime}, \mathrm{MPa}$ & $\tau, \mathrm{MPa}$ & $P_{\mathrm{pi}}, \mathrm{MPa}$ & $P_{\mathrm{pmax}}, \mathrm{MPa}$ & $\Delta P_{\mathrm{p}}$ & $\sigma_{\mathrm{nf}}^{\prime}, \mathrm{MPa}$ \\
\hline F1 & 3 & 37.99 & 7.54 & 19.13 & 44.0 & 24.9 & 13.12 \\
& 5 & 38.34 & 7.27 & 19.13 & 44.7 & 25.6 & 12.76 \\
$\mathrm{~F} 2$ & 3 & 42.07 & 3.64 & 22.04 & 57.4 & 35.4 & 6.71 \\
& 5 & 42.29 & 3.66 & 22.04 & 57.3 & 35.3 & 7.03 \\
$\mathrm{~F} 3$ & 3 & 32.52 & 7.85 & 19.87 & 38.8 & 18.9 & 13.59 \\
& 5 & 32.59 & 7.81 & 19.87 & 38.8 & 18.9 & 13.65 \\
F4 & 3 & 40.61 & 8.54 & 22.07 & 48.0 & 25.9 & 14.69 \\
& 5 & 40.67 & 8.48 & 22.07 & 47.9 & 25.8 & 14.85 \\
\hline
\end{tabular}


Slip tendency is defined as the ratio of shear to normal stress acting on the surface as follows:

$T_{\mathrm{s}}=\tau / \sigma_{\mathrm{n}}^{\prime}$

where $\tau$ is the shear stress, $\sigma_{\mathrm{n}}^{\prime}$ is the effective normal stress $\left(\sigma_{\mathrm{n}}-P_{\mathrm{P}}\right)$, and $T_{\mathrm{s}}$ is the slip tendency. For a cohesionless fault $(C=0)$, slip will be induced when $\tau / \sigma_{\mathrm{n}}^{\prime} \geq \mu$ (Rutqvist et al. 2007). Although using a frictional coefficient of 0.6 gives a conservative estimate of the maximum sustainable pore pressure during injection, it is a common assumption used in many similar studies (e.g., Rutqvist et al. 2007; Zoback 2007; Hung and Wu 2012; Konstantinovskaya et al. 2012; Figueiredo et al. 2015).

Hawkes et al. (2005) introduced the modified slip tendency $\left(T_{\mathrm{sm}}\right)($ Eq. 18) and demonstrated that fault slip risk is a function of the in situ stress magnitudes, pore pressure in the fault plane, orientation of the fault plane, and fault friction angle, as follows:

$T_{\mathrm{sm}}=\frac{\left(\sigma_{1}-\sigma_{3}\right) \sin 2 \delta}{\left[\left(\sigma_{1}+\sigma_{3}\right)+\left(\sigma_{1}-\sigma_{3}\right) \cos 2 \delta-2 P_{\mathrm{p}}\right] \tan \phi_{\text {fault }}}$

where $\sigma_{1}$ is the maximum principal in situ stress, $\sigma_{3}$ is the minimum principal in situ stress. $\delta$ is dip angle of the fault (with respect to horizontal) for a normal fault stress regime (in radians), $\Phi_{\text {fault }}$ is the fault friction angle (in radians) ( $31^{\circ}=0.54$ radians), and $P_{\mathrm{p}}$ is pore pressure in the fault plane. When $T_{\mathrm{sm}} \geq 1$, fault reactivation is expected. It is noteworthy that for all the methods used here (i.e., Mohr diagrams, slip tendency and modified slip tendency) the principal stresses were considered within a specified range (e.g., $10 \mathrm{~m}$ ) of the middle part of the fault planes.

According to Rutqvist et al. (2007) and Figueiredo et al. (2015), whenever the maximum principal effective stress exceeds three times the minimum compressive effective stress, shear slip will be induced. So, the critical pore pressure $\left(P_{\mathrm{C}}\right)$, which is required to induce slip on an arbitrarily oriented fault can be calculated as:

$P_{\mathrm{C}}=\frac{3 \sigma_{3}-\sigma_{1}}{2}$

After calculating the slip tendency for each fault in the current stress field and pore pressure using Eqs. 17 and 18, the critical pore pressure $\left(P_{\mathrm{Cr}}\right)$ was also calculated by Eq. 18 considering $T_{\text {sm }}=1$ (limit equilibrium) and Eq. 19 (Table 3).

According to Hawkes et al. (2005), in a normal fault stress regime, the faults that are most likely to slip first in any setting, tend to be those that strike sub-parallel to the intermediate in situ principal stress $\left(\sigma_{2}=\sigma_{\mathrm{Hmax}}\right)$ and dip at roughly $60^{\circ}$. In the field F1, F3 and F4 have strikes nearly parallel to the $\sigma_{\mathrm{Hmax}}$ orientation, but only the dip of F3 is $59^{\circ}$ (Fig. 7 and Table 1). Based on the results of both 3D Mohr
Table 4 Slip tendencies calculated using Morris et al. (1996) $\left(T_{\mathrm{s}}\right)$ and Hawkes et al. (2005) ( $\left.T_{\mathrm{sm}}\right)$ equations; critical pore pressures calculated from the Rutqvist et al. (2007) $\left(P_{\mathrm{c}}\right)$ and Hawkes et al. (2005) $\left(P_{\mathrm{Cr}}\right)$ equations

\begin{tabular}{llllll}
\hline Fault & Equation & $T_{\mathrm{s}}$ & $P_{\mathrm{c}}, \mathrm{MPa}$ & $T_{\mathrm{sm}}$ & $P_{\mathrm{Cr}}, \mathrm{MPa}$ \\
\hline F1 & 3 & 0.19 & 43.45 & 0.33 & 44.52 \\
& 5 & 0.18 & 44.28 & 0.32 & 45.32 \\
F2 & 3 & 0.04 & 55.03 & 0.08 & 57.58 \\
& 5 & 0.04 & 55.31 & 0.07 & 57.81 \\
F3 & 3 & 0.24 & 38.51 & 0.41 & 39.03 \\
& 5 & 0.24 & 38.64 & 0.40 & 39.16 \\
F4 & 3 & 0.21 & 45.34 & 0.35 & 48.45 \\
& 5 & 0.20 & 45.52 & 0.35 & 48.61 \\
\hline
\end{tabular}

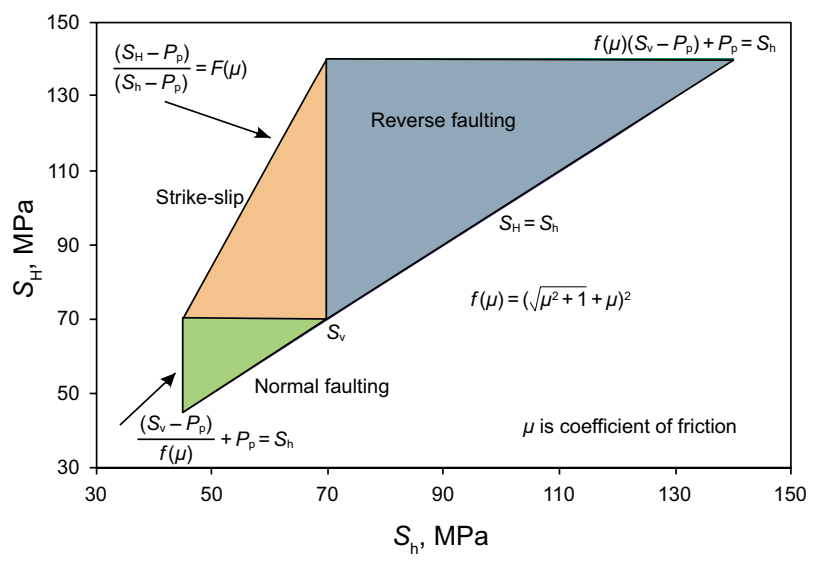

Fig. 12 Stress polygon showing different regions of stress regimes and formulations needed

diagrams (Table 3) and slip tendency equations (Table 4), F3 is more likely to reactivate, since its $\Delta P_{\mathrm{p}}$ and $P_{\mathrm{pmax}}$ are lower than the other faults. It also has the highest slip tendency value, which means it can reactivate with a lower pore pressure increase. On the other hand, F2 is the most stable fault, because it has the lowest $T_{\mathrm{s}}$ and $T_{\mathrm{sm}}$ and can undergo an average maximum pore pressure of 55-57 MPa.

\section{Stress polygon}

The stress polygon, which was introduced by Zoback et al. (1986) and Moos and Zoback (1990), is a method for visualizing the relationships between the magnitudes of overburden stress, and maximum and minimum horizontal stresses (Enderlin 2008). These polygons define the possible stress magnitudes at a given depth, a known pore pressure, and an assumed coefficient of friction (Zoback 2007). These polygons can also be used to demonstrate the stability of a fault in the current stress field if the values of three principal 
F1

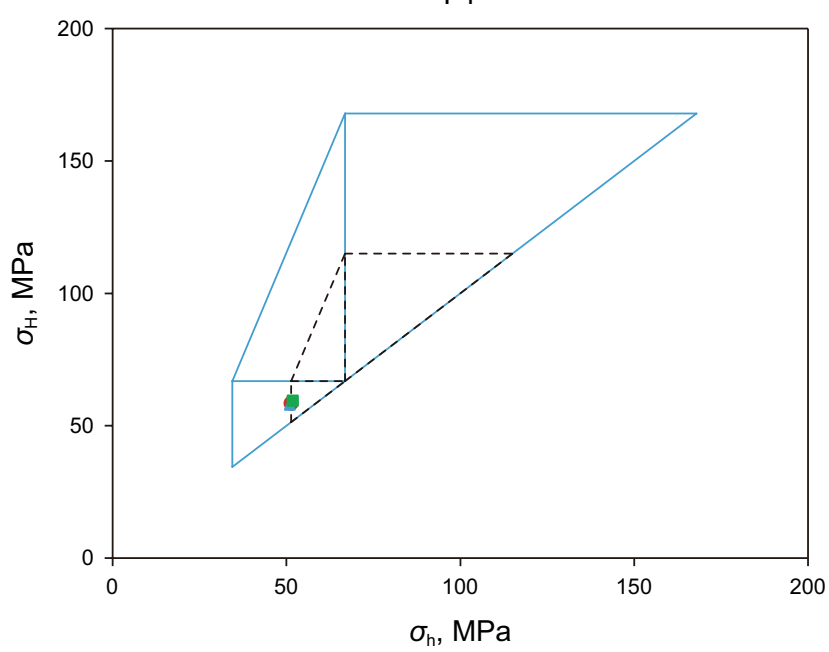

F3

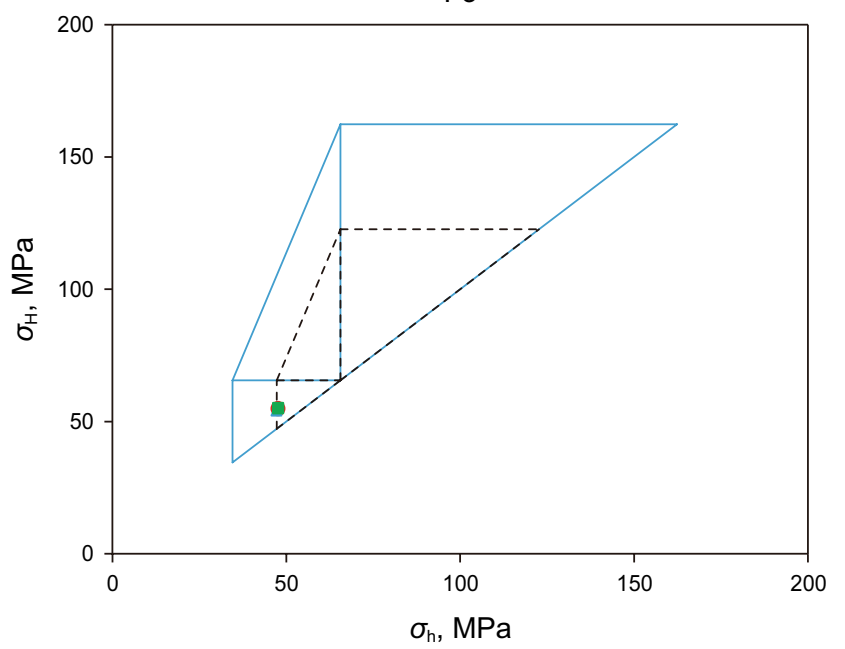

F2

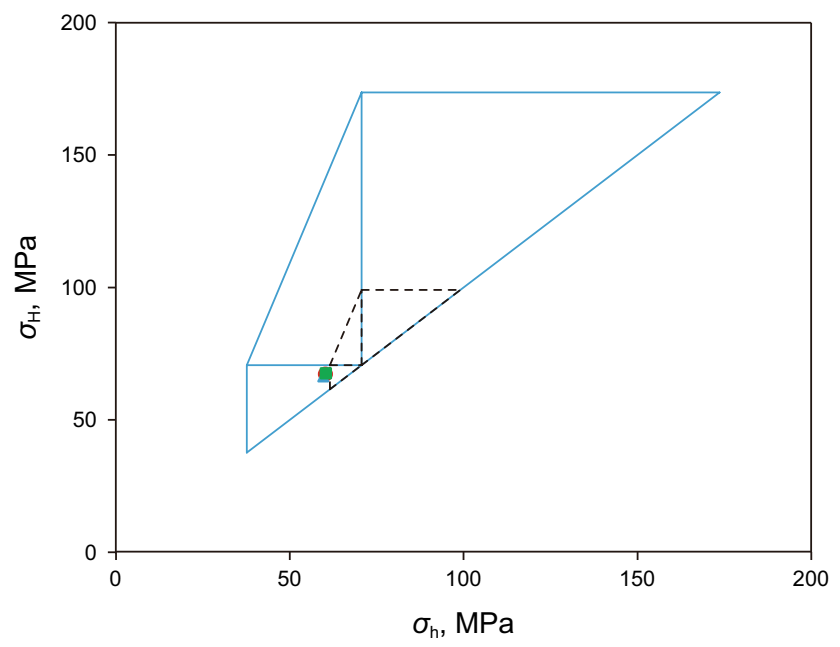

F4

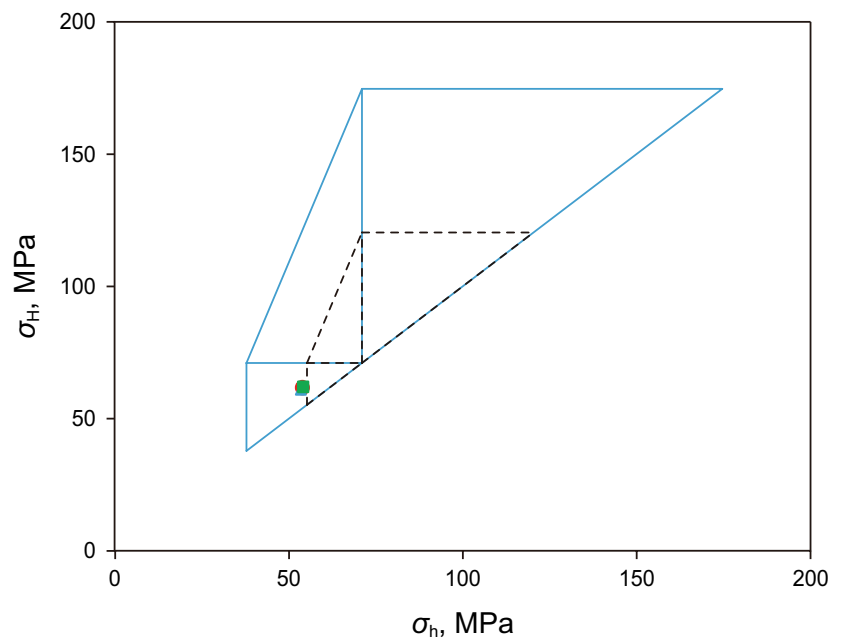

Fig. 13 Stress polygons plotted for the four faults. Three triangles NF, SS, and RF represent the normal, strike-slip and reverse faulting regimes, respectively. The blue solid lines represent the current stress field and pore pressure. Black dashed lines represent the stress field in critical pore pressure obtained by 3D Mohr diagrams. Circle and diamond shaped points represent the NISOC and Seyed Sajadi and Aghighi (2015) equations for obtaining elastic moduli used for estimating the horizontal stresses magnitudes

stresses are known. The horizontal stresses can be anywhere in the triangles, indicating a specific stress regime (i.e., normal, strike-slip and reverse). If the horizontal stresses are right on the edge, it is showing a Mohr circle touching the failure line, and the minimum horizontal stress and effective vertical stress are such that the fault is in the critical state. In case of normal faulting regime, $\sigma_{\mathrm{V}}$ is the maximum principal stress, $\sigma_{\mathrm{Hmax}}$ is less than or equal to $\sigma_{\mathrm{V}}$, and $\sigma_{\mathrm{hmin}}$ cannot be below a value determined by the frictional strength of crust. For this part, we also used a frictional coefficient of $\mu=0.6$, which corresponds to a $f(\mu)=3.1$. An example of a stress polygon and the formulations needed for plotting its different regions is shown in Fig. 12.
For inactive faults (not critically stressed), the horizontal stresses are within the normal faulting triangle (NF), and its Mohr circle does not touch the failure line, but when the horizontal stresses are on the left vertical edge of the normal faulting triangle, the fault is critically stressed (active fault) and the Mohr circle reaches the failure line. In this study, stress polygons were plotted for two states of current stress field and the critical pore pressure obtained by 3D Mohr diagrams (Fig. 13).

As Fig. 13 shows, all the faults are inactive at the present stress state, and the estimated horizontal stresses fall within the normal faulting triangle (triangle with solid lines). By increasing pore pressure to its critical value, horizontal stresses will be positioned on the left edge of the smaller 
triangle (triangle with dashed lines) showing the risk of reactivation. The NISOC equation (Eq. 3 ) shows a very close agreement to the Seyed Sajadi and Aghighi (2015) equation (Eq. 5), which confirms their validity for estimating elastic moduli in the reservoir.

\section{Conclusions}

Gachsaran oilfield, which is one of the most productive fields in Iran, requires primary EOR techniques such as gas injection to increase the amount of crude oil extraction. Reactivation of pre-existing faults is one of the major risks related to the use of such methods in reservoirs that can result in severe damage to the wellbores and other infrastructure. In this paper, the reactivation tendency of four faults in the Asmari reservoir in the field was analyzed using two analytical methods of 3D Mohr diagrams and slip tendency parameters. For this purpose, by using the equation derived in the NISOC laboratory, static elastic moduli were calculated to estimate the current stress regime of the field, and then the accuracy of the results was examined by the Seyed Sajadi and Aghighi (2015) equation. Results demonstrated that both equations are in accordance with each other. After that, 3D Mohr diagrams of the faults were plotted, which showed that all faults are stable in today's stress field and pore pressure. In order to evaluate the results of the 3D Mohr diagrams, the slip tendency factor was also calculated, and then the critical pore pressure of the faults due to gas injection was estimated. Results of all three methods of 3D Mohr diagrams, slip tendency and modified slip tendency, confirmed that F2 is the most stable fault in the field, and it can sustain a maximum pore pressure of 55-57 MPa. In the field F1, F3, and F4 have strikes sub-parallel to the $\sigma_{\mathrm{Hmax}}$ orientation, but only the dip of F3 is appropriate for reactivation. These results show that F3 is more prone to reactivation $\left(P_{\mathrm{pmax}}=38.8 \mathrm{MPa}\right)$. According to the results, the best location for an injection well in EOR and geosequestration activities will be the NW side of F2. Since the slip tendency factor can estimate the critical pore pressure with a good precision and without knowing the stress orientation, it will be more cost-effective in such studies, because of costliness and difficult interpretation of image logs.

Open Access This article is distributed under the terms of the Creative Commons Attribution 4.0 International License (http://creativeco mmons.org/licenses/by/4.0/), which permits unrestricted use, distribution, and reproduction in any medium, provided you give appropriate credit to the original author(s) and the source, provide a link to the Creative Commons license, and indicate if changes were made.

\section{References}

Anderson EM. The dynamics of faulting and dyke formation with applications to Britain. Edinburgh: Oliver and Boyd; 1951.

Azadpour M, Shad Manaman N, Kadkhodaie-Ilkhchi A, Sedghipour MR. Pore pressure prediction and modeling using well-logging data in one of the gas fields in south of Iran. J Pet Sci Eng. 2015;128:15-23. https://doi.org/10.1016/j.petrol.2015.02.022.

Berberian M, King GCP. Towards a paleogeography and tectonic evolution of Iran. Can J Earth Sci. 1981;18:210-65.

Byerlee JD. Friction of rocks. Pure Appl Geophys. 1978;116:615-26.

Darvishzadeh A. Geology of Iran: stratigraphy, tectonic, metamorphism, and magmatism. Tehran: Amir Kabir Press; 2009 (in Persian).

Eaton BA. The equation for geopressure prediction from well logs. Society of Petroleum Engineers of AIME. Paper SPE 5544; 1975.

Enderlin M. The Stress Polygon: 20 years later, still the tool for evaluating and integrating the scale of stress influence. AAPG Search and Discover Article, AAPG Annual Convention, San Antonio, Texas; 2008

Fjaer E, Holt RM, Horsrud P, Raaen AM, Risnes R. Petroleum related rock mechanics. Developments in petroleum science. 2nd ed. Amsterdam: Elsevier BV; 2008.

Figueiredo B, Tsang CF, Rutqvist J, Bensabat J, Niemi A. Coupled hydro-mechanical processes and fault reactivation induced by $\mathrm{CO}_{2}$ injection in a three-layer storage formation. Int $\mathrm{J}$ Greenhouse Gas Control. 2015;39:432-48. https://doi.org/10.1016/j. ijggc.2015.06.008.

Geological Society of Iran. www.geosociety.ir.

Hawkes CD, McLellan PJ, Bachu S. Geomechanical factors affecting geological storage of $\mathrm{CO}_{2}$ in depleted oil and gas reservoirs. J Can Pet Technol. 2005;44:52-61.

Hsieh PA, Bredehoft JD. A reservoir analysis of the Denver earthquakes: a case of induced seismicity. J Geophys Res. 1981;86:903-20.

Hung JH, Wu JC. In-situ stress and fault reactivation associated with LNG injection in the Tiechanshan gas field, fold-thrust belt of Western Taiwan. J Pet Sci Eng. 2012;96-97:37-48. https://doi. org/10.1016/j.petrol.2012.08.002.

Jaeger JC, Cook NGW. Fundamentals of rock mechanics. London: Methuen \& Co., Ltd; 1969.

James GA, Wynd JG. Stratigraphic nomenclature of Iranian oil consortium agreement area. Am Asso Petrol Geol Bull. 1965;49:2182-245.

Jolly RJH, Sanderson DJ. A Mohr circle reconstruction for the opening of a pre-existing fracture. J Struct Geol. 1997;19:887-92.

Kidambi T, Kumar GS. Mechanical Earth Modeling for a vertical well drilled in a naturally fractured tight carbonate gas reservoir in the Persian Gulf. J Pet Sci Eng. 2016;141:38-51. https://doi. org/10.1016/j.petrol.2016.01.003.

Konstantinovskaya E, Malo M, Castillo DA. Present-day stress analysis of the St. Lawrence Lowlands sedimentary basin (Canada) and implications for caprock integrity during $\mathrm{CO}_{2}$ injection operations. Tectonophysics. 2012;518-521:119-37. https://doi. org/10.1016/j.tecto.2011.11.022.

Kulikowski D, Amrouch K, Cooke D. Geomechanical modelling of fault reactivation in the Cooper Basin, Australia. Aust J Earth Sci. 2016;63(3):295-314. https://doi.org/10.1080/08120 099.2016.1212925.

Langhi L, Zhang Y, Gartrell A, Underschultz J, Dewhurst D. Evaluating hydrocarbon trap integrity during fault reactivation using geomechanical three-dimensional modeling: an example from Timor Sea, Australia. Am Asso Pet Geol Bull. 2010;94:567-91. https://doi.org/10.1306/10130909046. 
Mavko G, Mukerji T, Dvorkin J. The rock physics handbook, tools for seismic analysis of porous media. 2nd ed. New York: Cambridge University Press; 2009.

McKeagney CJ, Boulter CA, Jolly RJH, Foster RP. 3-D Mohr circle analysis of vein opening, Indarama lode-gold deposit, Zimbabwe: implications for exploration. J Struct Geol. 2004;26:1275-91. https://doi.org/10.1016/j.jsg.2003.11.001.

Mildren SD, Hillis RR, Lyon PJ, Meyer JJ, Dewhurst DN, Boult PJ. FAST: a new technique for geomechanical assessment of the risk of reactivation-related breach of fault seals. In: Boult P, Kaldi J, editors. Evaluating fault and cap rock seals, vol. 2. American Association of Petroleum Geologists. Hedberg Series; 2005. p. 73-85. https://doi.org/10.1306/1060757h23163.

Moos D, Zoback MD. Utilization of observation of wellbore failure to constrain the orientation and magnitude of crustal stresses: application to continental, Deep Sea Drilling Project, and Ocean Drilling Program boreholes. J Geophys Res. 1990;95:9305-25.

Morris A, Ferrill DA, Henderson DB. Slip-tendency analysis and fault reactivation. Geology. 1996;24:275-8.

Reynolds S, Hillis R, Paraschivoiu E. In situ stress field, fault reactivation and seal integrity in the Bight Basin, South Australia. Explor Geophys. 2003;34(3):174-81. https://doi.org/10.1071/EG03174.

Rezaie AH, Nogole-Sadat MA. Fracture modeling in Asmari reservoir of Rag-e Sefid oil field by using multiwall image log (FMS/FMI). Iran Int J Sci. 2004;5(1):107-21.

Rutqvist J, Birkholzer J, Cappa F, Tsang CF. Estimating maximum sustainable injection pressure during geological sequestration of $\mathrm{CO}_{2}$ using coupled fluid flow and Geomechanical fault slip analysis. Energy Convers Manag. 2007;48:1798-807. https://doi. org/10.1016/j.enconman.2007.01.021.

Rutqvist J, Rinaldi AP, Cappa F, Moridis GJ. Modeling of fault reactivation and induced seismicity during hydraulic fracturing of shale-gas reservoirs. J Pet Sci Eng. 2013;107:31-44. https://doi. org/10.1016/j.petrol.2013.04.023.

Rutqvist J, Rinaldi AP, Cappa F. Modeling fault activation and seismicity in geologic carbon storage and shale-gas fracturing-under what conditions could a felt seismic event be induced? In: SEG International Exposition and 87th Annual Meeting; 2017. p. 5391-5. https://doi.org/10.1190/segam2017-17749743.1.

Schmitt DR. Basic geomechanics for induced seismicity: a tutorial. CSEG Rec. 2014;39(11):24-9.

Seyed Sajadi S, Aghighi MA. Building and analyzing a geomechanical model of Bangestan reservoir in Kopal oilfield. Iran J Min Eng. 2015;10:21-34 (in Persian).

Shaban A, Sherkati S, Miri SA. Comparison between curvature and 3D strain analysis methods for fracture predicting in the Gachsaran oilfield (Iran). Geol Mag. 2011;148:868-78. https://doi. org/10.1017/S0016756811000367.

Shukla R, Ranjith P, Haque A, Choi X. A review of studies on $\mathrm{CO}_{2}$ sequestration and caprock integrity. Fuel. 2010;89:2651-64. https ://doi.org/10.1016/j.fuel.2010.05.012.

Stocklin J. Possible ancient continental margin in Iran. In: Burk CA, Drake CL, editors. Geology of continental margins. Berlin: Springer; 1974. p. 873-87.
Streit JE, Hillis RR. Estimating fault stability and sustainable fluid pressures for underground storage of $\mathrm{CO}_{2}$ in porous rock. Energy. 2004;29:1445-56. https://doi.org/10.1016/j.energy.2004.03.078.

Teatini P, Castelletto N, Gambolati G. 3D Geomechanical modelling for $\mathrm{CO}_{2}$ geological storage in faulted formations. A case study in an offshore northern Adriatic reservoir, Italy. Int J Greenhouse Gas Control. 2014;22:63-76. https://doi.org/10.1016/j.ijggc .2013.12.021.

Vilarrasa V, Makhnenko R, Gheibi S. Geomechanical analysis of the influence of $\mathrm{CO}_{2}$ injection location on fault stability. J Rock Mech Geotech Eng. 2016;8(6):805-18. https://doi.org/10.1016/j.jrmge .2016.06.006.

Wiprut D, Zoback MD, Hansen TH, Peska P. Constraining the full stress tensor from observations of drilling-induced tensile fractures and leak-off tests: application to borehole stability and sand production on the Norwegian margin. Int J Rock Mech Min Sci. 2000;34(3-4):365.e1-12. https://doi.org/10.1016/S1365 -1609(97)00157-3.

Wiprut D, Zoback MD. Fault reactivation, leakage potential, and hydrocarbon column heights in the northern North Sea. In: Koestler AG, Hunsdale R, editors. Hydrocarbon seal quantification, vol. 11, Norwegian Petroleum Society Conference, Stavanger, Norway, 16-18 October 2000. Norwegian Petroleum Society (NPF). Special Publications; 2002. p. 203-19. https://doi.org/10.1016/ s0928-8937(02)80016-9.

$\mathrm{Xu}$ S, Payne MA. Modeling elastic properties in carbonate rocks. Lead Edge. 2009;28:66-74. https://doi.org/10.1190/1.3064148.

Xu SS, Nieto-Samaniego AF, Alaniz-Álvarez SA. 3D Mohr diagram to explain reactivation of pre-existing planes due to changes in applied stresses. In: Xie F, editor. Rock stress and earthquakes. London: Taylor \& Francis Group; 2010. p. 739-45. https://doi. org/10.13140/2.1.2099.6489.

Yin ZM, Ranalli G. Critical stress difference, fault orientation and slip direction in anisotropic rocks under non-Andersonian stress systems. J Struct Geol. 1992;14:237-44.

Zoback MD. Reservoir Geomechanics. New York: Cambridge University Press; 2007.

Zoback MD, Barton CA, Brudy M, Castillo DA, Finkbeiner T, Grollimund BR, Moos DB, Peska P, Ward CD, Wiprut DJ. Determination of stress orientation and magnitude in deep wells. Int J Rock Mech Min Sci. 2003;40:1049-76. https://doi.org/10.1016/j.ijrmm s.2003.07.001.

Zoback MD, Gorelick SM. Earthquake triggering and large scale geologic storage of carbon dioxide. Proc Natl Acad Sci. 2012;109(26):10164-8. https://doi.org/10.1073/pnas.1202473109.

Zoback MD, Mastin L, Barton C. In-situ stress measurements in deep boreholes using hydraulic fracturing, wellbore breakouts and Stonely wave polarization. In: ISRM International Symposium, 31 August-3 September, Stockholm, Sweden; 1986. 